International Research Journal of Management, IT \& Social Sciences
Available online at https://sloap.org/journals/index.php/irjmis/
Vol. 7 No. 6, November 2020, pages: 161-166
ISSN: 2395-7492
https://doi.org/10.21744/irjmis.v7n6.1032

\title{
How Educational Technology Innovates Distance Learning During Pandemic Crisis in Remote Areas in Indonesia?
}

\begin{tabular}{|c|c|}
\hline & Rayuwati $^{a}$ \\
\hline Article history: & Abstract \\
\hline $\begin{array}{l}\text { Submitted: } 18 \text { September } 2020 \\
\text { Revised: } 27 \text { October } 2020 \\
\text { Accepted: } 09 \text { November } 2020\end{array}$ & $\begin{array}{l}\text { This study presents the results of a review of seven international publications } \\
\text { that discuss how technology can innovate distance learning during a pandemic } \\
\text { crisis in remote areas in Indonesia. It cannot be denied that technology services } \\
\text { are quite large in helping the learning of the nation's children all over } \\
\text { Indonesia. However, we should cool off on educational researchers' findings, } \\
\text { especially technology-based learning innovations, which are now increasingly }\end{array}$ \\
\hline $\begin{array}{l}\text { Keywords: } \\
\text { education technology; } \\
\text { learning innovation; } \\
\text { online learning; } \\
\text { pandemic crisis; } \\
\text { remote learning; }\end{array}$ & $\begin{array}{l}\text { being used in all business and educational activities of the younger generation. } \\
\text { We have conducted a review of various literature. Then we continue with a } \\
\text { review of ten publications on the role and impact of technology applications } \\
\text { on the sustainability of learning in areas where internet networks are still tricky } \\
\text { issues. To prove the claim, we conducted a qualitative analysis in a } \\
\text { phenomenological and in-depth understanding to ensure that our findings were } \\
\text { based on validity and reliability. }\end{array}$ \\
\hline
\end{tabular}

International research journal of management, IT and social sciences (C) 2020.

This is an open access article under the CC BY-NC-ND license (https://creativecommons.org/licenses/by-nc-nd/4.0/).

Corresponding author:

Rayuwati,

Universitas Gajah Putih, Indonesia.

Email address: rayuwati68@gmail.com

Universitas Gajah Putih, Indonesia 


\section{Introduction}

Since the emergence of COVID-19 in Indonesia in early 2020, all human life and business sectors have continued to be affected, including the education and teaching sector, both in cities and in remote areas. The impact occurred not because of a deadly virus, but the impact of government policies on how to respond to calls from the World Health Organization and UNESCO education about the dangers of the virus attacking the health of billions of students. Reduce the burden and backwardness in education due to the policy of responding to the spread of COVID-19 by closing schools, online technical assistance based education continues to be the leading choice for both school and university levels. Since the technology-based learning program has been going on for almost a year, we are called to examine how the effectiveness of technological innovation on student learning during the pandemic crisis has helped the continuation of student learning programs, especially in remote areas of Indonesia.

Before we continue discussing the core of the problem, we should explain a little what and why to learn by innovating technology during a pandemic. The implementation of online learning-based learning stems from a government policy through the education and culture office, which issued several policies to regulate learning activities during this pandemic. It was issued through Circular No. 4 of 2020, namely regarding the Implementation of Education Policies in an Emergency for the Spread of Coronavirus Disease (COVID-19), dated March 24, 2020. Six policies are clearly outlined. However, here we want to discuss the most basic, among others innovating how to teach students and teachers. So the policy was born to send students home to study from home to save lives and remain active in learning remotely. Many parties admit that learning from home is quite challenging because the learning system in Indonesia, especially in remote areas, is not used to a computer-based system, let alone an internet connection network. It is an unusual way of learning habits by both students and teachers themselves.

How is it not a problem? So far, teachers and students learn and teach in class because they gather in a school environment with a teaching and learning function supported using supporting the teaching and learning process in real-time and real person. With this new policy, teachers and the school community are confused because they are still looking for the right pattern of how learning from home can be done. Not to mention the limitations of facility and access to virtual learning-based technology like studying in big cities and even learning models in the style of developed countries such as Singapore and other developed countries. Like it or not, the best solution, even though it is challenged, is to carry out or strive for learning based on computer networks to computers or systems to the latest technology devices. Another name people mention is online learning.

Technically, online innovation-based learning is very different from conventional learning that occurs in schools. Teachers and students do not face to face but occur remotely, allowing teachers and students to be in different places, with different commitments and skills in the operation of technology. Not to mention that this policy is a bit sudden to learn with technology even though before COVID-19 appeared, teachers and students in remote areas were not used to it, and some schools seemed to forbid students to be caught carrying gadget tools into the school environment. This matter is also an irony in educational systems and policies in remote areas that are very contradictory to the needs of implementing educators and learning in the era of high technology long before pandemics and other crises occur.

Thus, positively, this technology-based learning is beneficial for the continuity of learning in this pandemic period with all the obstacles and challenges. Because teachers, students, and other school communities will remain safe in their respective places or homes without having to leave the house and meet face to face, which has been obeyed even though until now it is not clear how dangerous it is if students continue to enter school, especially schools in remote areas. Areas where the spread of COVID-19 is not as bad as in other big cities. Like what Viner et al., (2020) studied, that school closure and management practices during coronavirus outbreaks including COVID-19, which had not been tested, the school environment became the center for the spread of COVID-19 through a rapid systematic review that they conducted on dozens of study data from various countries and regions. However, that is what happens that schools must be closed, and the solution is to learn from home using education-based technology (Stein \& Harel-Shalev, 2019; Putra et al., 2020).

Online-based learning or virtual learning has become a cutting-edge and global solution in developed and other developing countries. Study after study is needed to ensure the extent of its effectiveness, especially its application system in student classrooms and geographically, they are not as good as education services in big cities have reached the target or not. With the hope, this finding will be a significant input for schools, especially the government, in education to improve the quality of policies on the learning system, especially during the pandemic and other social crises. 


\section{Materials and Methods}

As mentioned above, the purpose of this study is to determine the effectiveness of innovating technology as a solution to student learning disorders in remote areas during the COVID-19 pandemic. To make it easier for us to understand and answer the problems of studying education based on computer technology and internet solutions, we first conducted a preliminary reading of literature and other informatics technology-based learning documents. After all, data has been collected; we analyze it in depth under the phenomenology approach's direction. Because this study is qualitative, we involve a coding system and in-depth interpretation so that the findings of this study are genuinely reliable for their validity. We used an online data search engine with a searching keywords system because we did this study in the pandemic era. For example, "learning during a pandemic," learning based on internet connection data, "learning innovation in the pandemic era," and "learning in a remote area." Finally, we arrive after the findings from a review of ten publications on the effectiveness of internet-based learning in informatics in the era of COVID-19 disruption in the regions remote in Indonesia.

\section{Results and Discussions}

The World Bank (2020), responds to the COVID-19 crisis by supporting tertiary teaching and education for school continuity and adapting and innovating all technological resources. To be able to maintain an effective quality education system and services. Such services can reduce the backwardness of standardized education because students are outside the school system, unable to engage in face-to-face active learning like schools before the COVID-19 disorder. The world institution is confident about the future of world education and the prospects for disruption during the pandemic. Likewise, the findings of Javaid et al. (2020), which look at industrial technology 4.0 and applications in overcoming educational disruptions during the COVID-19 pandemic, have supported the education journey. They recommended some useful findings from Industry 4.0 that helped control and control education management, especially teaching after COVID-19 appeared. They convey how the currently available Industry 4.0 technology can help protect continuing education and diagnose COVID-19 and other related problems.

The findings of Ferdig et al. (2020), said that teaching and technology had become a solution where teachers during the pandemic in the field and the findings of the association for the advancement of computing in education development have worked together to be licensed No Derivatives International 4.0. (Aslan, 2020; Putra et al., 2020). They all described how heavy the burden of education was after the pandemic emerged so that all parties must see that technological solutions are still very relevant in solving the problem of learning scarcity when hit by COVID-19. Likewise, Bayham \& Fenichel (2020), which looks at the impact of closing all schools for the reason of COVID-19 on the health and education workforce in the US and the death of Tota, has initiated this modeling study in which many countries in Asia and Europe have institutionalized school closings nationally, while US school districts and states. This closure prevents contact between children and reduces cases. However, closing schools has drawbacks, even if the sole purpose of such measures is to save lives while using technological tools to save learning from home.

The study of Tamah et al. (2020), found five essential aspects in the distance learning process: students, teacher skills before virtual learning, technology, pedagogical knowledge, and learning support devices. This study emphasizes teachers' readiness aspects who are still struggling to pursue digital learning services. Given the teacher council's awareness of their lack of distance learning delivery and a renewed commitment, these teachers have high hopes that they will one day increase their independence and professional advancement in the area of distance teaching skills one day.

Study et al. (2020) regarding the distance learning strategy during COVID-19 at the elementary school level in Indonesia has had a tremendous impact, especially for families whose families are socially and economically disadvantaged. The shift from face-to-face classroom methods to home-based remote learning systems shows the need to develop teachers' ability to renovate technology into solving learning difficulties (Gomez et al., 2020). Therefore, their research suggests how distance learning strategies during the COVID-19 period should be with the right strategy for solving problems, including online learning or e-learning, online teaching as a need, problems related to online learning, solutions that are perhaps for this issue, policy approval for the Indonesian government, and primary school distance learning strategies.

The findings of Suryaman et al. (2020), on COVID-19 and studying virtual ways of questioning the impact on the quality of learning in pharmaceutical science. The result was that there were several obstacles felt by school communities in virtual teaching and learning process, namely mastery of technological tools is still an educational

Rayuwati, R. . (2020). How educational technology innovates distance learning during pandemic crisis in remote areas in Indonesia?. International Research Journal of Management, IT and Social Sciences, 7(6), 161-166.

https://doi.org/10.21744/irjmis.v7n6.1032 
issue. In additional internet quota costs, additional work for parents in assisting children in learning, communication, and socialization between students. They added that the COVID-19 pandemic also affects huge problems including teachers' life, parents, students, and the teaching process, as a teacher who has the responsibility to educate students cannot stop. According to them, teachers must find appropriate ways to promote the learning activity academically and social matters. Teachers have been able to conduct classrooms in the online system.

Abel Jr (2020), studied the phenomenon of online learning through remote system learning during an emergency pandemic crisis. He managed to pinpoint some of the reasons for barriers to remote learning, such as family economic factors such as not being able to access the internet, lack of technological devices, and environmental or family support. Most interestingly, their findings from distance learning in these times of emergency are challenging because of the many problems that exist with access and affordability by families, and emerging concerns about economic stability and learning support contribute to interrupt learning activeness.

Lipomi (2020), examines student guardians' understanding of remote system learning activities during the Pandemic in remote villages in Indonesia. Their study found that a lack of parental concern for student learning activities at home was why unsuccessful online emergency learning activities during difficult times. Parent reasons include lack of time and their inability to substitute teachers for students in their homes. Only a few parents understand that their task is to assist and support children's learning at home to provide internet connection packages, help children with learning assignments, and participate in completing mandatory assignments or tests sent by teachers. The most surprising finding was that the children's enthusiasm for learning had dropped so that next year, their parents hoped that the school would reopen to study in class and students could meet their friends.

The findings of the World Bank that respond to the learning crisis of the impact of COVID-19 by promoting teaching and education with technology adaptation for the continuity of learning and innovation of all technological resources have not had a fully positive impact, such as continuous and sustainability of learning after COVID-19. Montacute (2020), wrote that the government's move in empowering online learning with technology has implications for inequality of education in Indonesia, especially for regions and remote areas of the country that have not to access government service networks. The reason for Montacute is, among others, efforts to expand the internet connection network with private tuition fees in online learning. Ease of access to learning technology and online resources for students from underprivileged backgrounds when schools are closed. A fair internet network is indeed a major issue in both college and school.

Likewise, Adnan \& Anwar (2020), highlighted the implementation of virtual-based learning during the COVID19 pandemic crisis by asking for students' opinions. Their findings have also produced findings that are different from the hypothesis of this study that according to their understanding, learning how to online is difficult during the COVID$19-19$ this cannot give maximum results in underdeveloped countries where most students cannot reach the internet due to technical problems and socio-economic factors. The lack of face-to-face learning with teachers, time to provide a direct response, and the absence of traditional classroom outreach are other things the graduate student highlighted. It must be admitted that this pandemic has made several institutions difficult to carry out activities and educational activities that have become increasingly difficult with the application of online-based learning because the school and student families must provide full support by teaching in a mechanism that has never happened before. All classrooms commonly used for face-to-face learning must now be replaced with online technology assistance systems that are actually of high innovation and modern value - but suddenly forced to study from his home to avoid the coronavirus not necessarily effective in saving students (Viner et al., 2020).

Because learning is transferred very suddenly from face to face to distance learning, it cannot be anticipated properly. Most schools in Indonesia, especially those in remote areas, were not designed to be used before COVID-19 appeared. Understanding distance learning is still limited to listening, but not yet the skill in implementing it without proper preparation of tools or training for teaching staff, such as teachers designing and implementing virtual learning programs. Likewise, students do not have the option to prepare for the transition in pandemic learning. Despite all of the above limitations, every student has tried their best to create a better climate of situation, fast and enhanced online access to education in a time unprecedented before COVID-19.

Allo (2020), said that indeed online learning is not as easy as we imagine. Many students and teachers have reported that they encountered obstacles due to 'stuttering' with this online learning. Teachers who could not teach directly encountered obstacles even though the activities were carried out using video calls. Many of the students' learning material is difficult to understand because of the many disturbances when carrying out activities. The problem is because when learning face-to-face, the lessons that must be modeled are better face-to-face; if this is constrained because it is not direct like students are wrong and disturbed by signals, the material cannot be conveyed properly. Likewise, because sometimes parents of students cannot be contacted by the teachers and schools, the parents who 
work have limited tools. Some parents are busy working because the role of parents is needed. Children who learn from home also do not focus on studying because the home environment is indeed busy, so it is disturbed. As a result, learning cannot be implemented effectively. It is the real situation when learning with the help of technology is in reality.

Giatman et al. (2019), believe that the effectiveness of digital learning and teaching and learning engaging in the innovation design of education and virtual education. Even though the impact of implementing online learning during COVID-19 still has many weaknesses and shortcomings, many parties still expect the benefits and solutions provided by online learning when viewed from a practical and productive point of view (Song et al., 2004; Chen \& Jang, 2010). The interaction between teachers and students will be more practical with online learning because they don't have to travel to meet, especially in today's difficult times. Besides, there are no classrooms for formal learning. The process of teaching and learning process can occur anywhere as long as it is conducive and can help focus. Also, no extras such as necessities are required.

Although the government has taken many steps promptly to support learning from home as long as COVID-19 remains a major challenge for education, the most acceptable step is still the online way. Del Rio-Chanona et al. (2020), assumed that the pandemic's shocks and disruptions cause a decrease in income, technology-based learning experts estimate that an additional number of children in Indonesia, especially those in remote areas, will experience dropouts - an increase of 0.13 in the percentage of primary school dropouts. Assuming that most schools remain closed until the end of July, according to our calculations, on average, students will lose about a third of what they should learn in one year. It turns out that the conditions of learning are related to their capacity to produce something in the future. Because through online learning, they get the skills they need to be productive. If schools remain closed for a long time without additional measures to support learning such as allowances for online learning support devices, education's disadvantages will be even greater. Thus, even though online learning activities have not been able to solve learning with results as expected in big cities in remote areas, learning efforts on how to innovate online technology are still very relevant (Westera \& Wagemans, 2007).

\section{Conclusion}

The disruption of COVID-19 to education is caused by government policies to stop the spread of the virus by temporarily closing schools so that the teaching and learning process is disrupted in all school and university institutions and returning students to study at home only with technical guidance. As a concrete directive from the government, in March 2020, schools will be closed simultaneously. Following these rules, all schools were closed and replaced by distance learning even there are some handicaps appear especially the students who are living in remote areas.

As stated above, this study wants to understand how remote learning technology can innovate learning from home or a distance during a pandemic crisis in rural areas in Indonesia. Considering various literature and the results of studies of public objectives in various educational and teaching journals during the COVID-19 outbreak, we can conclude that the majority of papers still place the importance of the existence of technology in supporting educational innovation today. Even though other findings see many disadvantages of distance learning with technological innovation in remote areas, we do not turn away to that which is very true with all the available evidence. However, when seeing the condition of education is still very disturbed by the issue of the COVID-19 outbreak, this study still understands that the existence of technology is still very relevant to be applied even in remote areas as long as the government's concern with the community can support the provision of supporting online learning facilities.

\section{Conflict of interest statement}

The author declared that she has no competing interests.

\section{Statement of authorship}

The author has a responsibility for the conception and design of the study. The author has approved the final article.

Acknowledgments

I am grateful to two anonymous reviewers for their valuable comments on the earlier version of this paper.

Rayuwati, R. . (2020). How educational technology innovates distance learning during pandemic crisis in remote areas in Indonesia?. International Research Journal of Management, IT and Social Sciences, 7(6), $161-166$.

https://doi.org/10.21744/irjmis.v7n6.1032 


\section{References}

Abel Jr, A. (2020). The phenomenon of learning at a distance through emergency remote teaching amidst the pandemic crisis. Asian Journal of Distance Education, 15(1), 127-143.

Adnan, M., \& Anwar, K. (2020). Online Learning amid the COVID-19 Pandemic: Students' Perspectives. Online Submission, 2(1), 45-51.

Allo, M. D. G. (2020). Is the online learning good in the midst of Covid-19 Pandemic? The case of EFL learners. Jurnal Sinestesia, 10(1), 1-10.

Aslan, A. (2020). Pengembangan Bahan Ajar Berbasis Imtaq Dan Iptek Di Era Revolusi Industri 4.0 Pada Mata Pelajaran Sains Madrasah Ibtidaiyah. TaLimuna: Jurnal Pendidikan Islam, 9(1), 1-15.

Bayham, J., \& Fenichel, E. P. (2020). The impact of school closure for COVID-19 on the US healthcare workforce and the net mortality effects. Available at SSRN 3555259.

Chen, K. C., \& Jang, S. J. (2010). Motivation in online learning: Testing a model of self-determination theory. Computers in Human Behavior, 26(4), 741-752. https://doi.org/10.1016/j.chb.2010.01.011

Del Rio-Chanona, R. M., Mealy, P., Pichler, A., Lafond, F., \& Farmer, D. (2020). Supply and demand shocks in the COVID-19 pandemic: An industry and occupation perspective. arXiv preprint arXiv:2004.06759.

Ferdig, R. E., Baumgartner, E., Hartshorne, R., Kaplan-Rakowski, R., \& Mouza, C. (2020). Teaching, technology, and teacher education during the covid-19 pandemic: Stories from the field. Waynesville, NC, USA: Association for the Advancement of Computing in Education (AACE).

Giatman, M., Haq, S., \& Pratama, Y. F. (2019, November). Effectivity of Online Learning Teaching Materials Model on Innovation Course of Vocational and Technology Education. In Journal of Physics: Conference Series (Vol. 1387, No. 1, p. 012131). IOP Publishing.

Gomez, E., Azadi, J., \& Magid, D. (2020). Innovation born in isolation: Rapid transformation of an in-person medical student radiology elective to a remote learning experience during the COVID-19 pandemic. Academic radiology, 27(9), 1285-1290. https://doi.org/10.1016/j.acra.2020.06.001

Javaid, M., Haleem, A., Vaishya, R., Bahl, S., Suman, R., \& Vaish, A. (2020). Industry 4.0 technologies and their applications in fighting COVID-19 pandemic. Diabetes \& Metabolic Syndrome: Clinical Research \& Reviews. https://doi.org/10.1016/j.dsx.2020.04.032

Lipomi, D. J. (2020). Video for Active and Remote Learning. Trends in Chemistry. https://doi.org/10.1016/j.trechm.2020.03.003

Montacute, R. (2020). Social Mobility and Covid-19: implications of the Covid-19 crisis for educational inequality.

Putra, P., Liriwati, F. Y., Tahrim, T., Syafrudin, S., \& Aslan, A. (2020). The Students Learning from Home Experiences during Covid-19 School Closures Policy In Indonesia. Jurnal Iqra': Kajian Ilmu Pendidikan, 5(2), 30-42.

Putra, P., Mizani, H., Basir, A., Muflihin, A., \& Aslan, A. (2020). The Relevancy on Education Release Revolution 4.0 in Islamic Basic Education Perspective in Indonesia (An Analysis Study of Paulo Freire's Thought). Test Engineering \& Management, 83, 10256-10263.

Song, L., Singleton, E. S., Hill, J. R., \& Koh, M. H. (2004). Improving online learning: Student perceptions of useful and challenging characteristics. The internet and higher education, 7(1), 59-70. https://doi.org/10.1016/j.iheduc.2003.11.003

Stein, A. A., \& Harel-Shalev, A. (Eds.). (2019). Affect, Interest and Political Entrepreneurs in Ethnic and Religious Conflicts. Routledge.

Suryaman, M., Cahyono, Y., Muliansyah, D., Bustani, O., Suryani, P., Fahlevi, M., ... \& Munthe, A. P. (2020). Covid19 Pandemic And Home Online Learning System: Does It Affect The Quality Of Pharmacy School Learning?. Systematic Reviews in Pharmacy, 11(8), 524-530.

Tamah, S. M., Triwidayati, K. R., \& Utami, T. S. D. (2020). Secondary school language teachers' online learning engagement during the COVID-19 pandemic in Indonesia. Journal of Information Technology Education: Research, 19, 803-832.

Viner, R. M., Russell, S. J., Croker, H., Packer, J., Ward, J., Stansfield, C., ... \& Booy, R. (2020). School closure and management practices during coronavirus outbreaks including COVID-19: a rapid systematic review. The Lancet Child \& Adolescent Health. https://doi.org/10.1016/S2352-4642(20)30095-X

Westera, W., \& Wagemans, L. (2007). Help me! Online learner support through the self-organised allocation of peer tutors. In 13th International Conference on Technology Supported Learning \& Training (pp. 105-107).

World Bank. (2020). The COVID-19 Crisis Response: Supporting Tertiary Education for Continuity, Adaptation, and Innovation. 